\title{
INVESTIGATION OF HEAVY METALS BATTERY IN THE SOFT BODY OF THE FRESHWATER MUSSELS OF GENUS ANODONTA
}

\author{
N. Golovko, T. Golovko, A. Gelikh \\ Kharkov State University of Food Technology and Trade
}

\begin{tabular}{l}
$\quad$ Key words: \\
Heavy metals \\
Accumulation \\
Penetration \\
Freshwater mussels of the \\
genus Anodonta \\
Soft body \\
\hline
\end{tabular}

Article history:

Received 11.09.2018

Received in revised form 28.09.2018

Accepted 09.10.2018

Corresponding author:

N. Golovko

E-mail:

npnuht@ukr.net

\begin{abstract}
Features of accumulation of heavy metals in ecosystems of fish breeding ponds in the Sumy region were investigated. Features of the accumulation and distribution of heavy metals in the soft body of freshwater mussels of the genus Anodonta were defined. The results of the research indicate that the concentration of heavy metals in the studied components of the ecosystem of the fishery pond is in line with the existing norms. The content of heavy metals such as cadmium, plumbum and zinc in the soft body of the studied species of mussels did not exceed the normative values. The ways of receipt and accumulation of heavy metals in the soft body of freshwater mussels of the genus Anodonta were investigated. The dependence of their penetration and accumulation depending on the method of feeding and properties of metal ions were analyzed. The degree of accumulation of metals in the tissues of mussels was determined in relation to the content of elements in water.

The coefficient of biological accumulation (CBN) was calculated, which is understood as the ratio of the concentration of heavy metals in the soft body of freshwater mussels to their quantitative content in the environment. It was proved that the concentrations of heavy and other toxic metal ions in the studied components of the hydrosystem of the reservoir were correlated with their normative values. The content of heavy metals in the tissues of the studied species of mussels is within the limits of permissible norms. It was determined that the coefficients of biological accumulation indicate not only the pollution of the environment with these metals, but also the biological availability of their ions in these conditions, and also indicate a low accumulation of trace elements of mussels.
\end{abstract}

DOI: $10.24263 / 2225-2924-2018-24-5-6$ 


\title{
ДОСЛІДЖЕННЯ АКУМУЛЯЦІї ВАЖКИХ МЕТАЛІВ У М'ЯКОМУ ТІЛІ ПРІСНОВОДНИХ МОЛЮСКІВ POДY ANODONTA
}

\author{
М.П. Головко, Т.М. Головко, А.О. Геліх \\ Харківський державний університет харчування та торгівлі
}

У статті досліджено особливості накопичення важких металів в екосистемах рибницьких ставів у Сумській області. Визначено особливості накопичення і розподілу важких металів у м'якому тілі прісноводних молюсків роду Anodonta. Наведені результати досліджень свідчать про відповідність концентрації важких металів у досліджуваних компонентах екосистеми рибницького ставу існуючим нормам. Вміст важких металів (кадмію, плюмбуму, ичинк і купруму) в м'якому тілі досліджуваних видів молюсків не перевищував нормативних значень. Досліджено иляхи надходження та акумулювання важких металів у м'якому тілі прісноводних молюсків роду Anodonta. Проаналізовано залежність їх проникнення та накопичення залежно від способу живлення та властивостей іонів металів. Визначено ступінь акумулячї металів у тканинах молюсків відносно вмісту елементів у воді.

Розрахований коефічієнт біологічного накопичення $\left(K_{\text {Бн }}\right)$, під яким розуміють відношення концентрації важких металів у м'якому тілі прісноводних молюсків до їх кількісного вмісту в навколишньому середовищі. Доведено, щзо концентрації важких та інших токсичних іонів металів у досліджуваних складових гідроекосистеми водоймища корелюють з їх нормативним значенням. Вміст важких металів у тканинах досліджуваних видів молюсків перебуває в межах допустимих норм. Визначено, щуо коефіцієнти біологічного накопичення свідчать не тільки про забруднення середовища цими металами, але й про біологічну доступність їх іонів у таких умовах, а також вказують на невисоку акумуляцію мікроелементів молюсками.

Ключові слова: важкі метали, акумулювання, проникнення, прісноводні молюски роду Anodonta, м'яке тіло.

Постановка проблеми. В останні десятиліття в екосистемах водойм спостерігаються зміни, які відбуваються під впливом природних факторів навколишнього середовища і під впливом господарської діяльності людини. Тому особливої актуальності набувають дослідження закономірностей реакцій прісноводних молюсків на мінливі умови навколишнього середовища. Загрозу для життєдіяльності гідробіонтів, що досліджуються, представляють важкі метали та їх сполуки [3; 4]. У сучасних екологічних умовах однією 3 найбільш гострих екологічних проблем, що стосуються гідросфери, є забруднення басейнів малих річок, які через незначні площі водозборів найбільш вразливі до негативного техногенно-антропогенного впливу. Відомо, що малі річки безпосередньо впливають на гідрохімічний склад та якість води середніх і великих річок, а в їхніх басейнах формується понад 60\% водних ресурсів 
України [4]. Особливо небезпечними за впливом на екологічну систему водних об'єктів є важкі метали. Високий рівень забруднення середовища важкими металами призводить до зниження видового різноманіття гідробіонтів. Використання гідробіонтів як біоіндикаторів дає змогу визначити значення цих токсикантів. Групу важких металів можна віднести до мікроелементів. 3 одного боку, одні вкрай необхідні для життєзабезпечення живих організмів, інші викликають протилежний ефект i, потрапляючи в організм, призводять до його отруєння або загибелі. Фахівцями 3 охорони навколишнього середовища серед металів-токсикантів виділена пріоритетна група, в яку входять кадмій, мідь, миш'як, нікель, ртуть, свинець, цинк і хром як небезпечні для живих організмів; $з$ них ртуть, свинець і кадмій — найбільш токсичні [5-7]. Тому доцільно проводити визначення вмісту металів як у тканинах молюсків, так і в середовищі їх проживання - воді, тому що наявні у водних системах іони важких металів поглинаються організмами та накопичуються у м'якому тілі молюсків і в подальшому передаються по ланцюгу харчування [3].

Такі метали, як цинк, марганець, мідь і ферум у фізіологічних концентраціях є життєво необхідними для здійснення регуляторних функцій в організмі гідробіонтів, передусім як складові ферментів. Разом $з$ тим перелік важких металів містить елементи, біологічну роль у живих організмах для яких не визначено, і які токсично впливають навіть у незначних концентраціях. До таких елементів належать свинець і кадмій [2]. Відомо, що накопичення важких металів в організмі гідробіонтів, зокрема молюсків, залежить від геохімічних чинників середовища, типу водойми, функціонального стану організму та особливостей живлення [5]. Питання кількості накопиченні окремих важких металів в організмі прісноводних молюсків вивчено меншою мірою.

Визначені основні цілі, які стоять перед комплексним дослідженням м'якого тіла молюсків півночі України в технології напівфабрикату. Необхідно дослідити не лише оптимальні режими технологічних операцій, при яких максимально збережуться структурно-механічні та органолептичні властивості м'якого тіла, але й екологічну доброякісність і безпечність сировини. Виконання поставлений цілей надасть можливість підвищити конкурентоспроможність продуктів 3 гідробіонтів, що є надзвичайно своєчасним та економічно виправданим завданням.

Аналіз останніх досліджень і публікацій. Зміна сировинної бази і зниження обсягів вилову морських молюсків пов'язані з екологічним становищем [2]. Це викликало необхідність перегляду об'єктів сировинної бази для виготовлення напівфабрикатів і готових кулінарних виробів, а також внесення змін до їх технології виробництва. Кількісний вміст важких металів та особливості їх локалізації у м'якому тілі молюсків є предметом досліджень вчених як 3 близького [3; 4], так і далекого зарубіжжя [5-8].

Досить інтенсивно дослідження особливостей накопичення важких металів гідробіонтами проводяться в країнах Африки [5], Південно-Східної Азії й Близького Сходу [5-8]. В Україні цій проблемі присвячено також низку 
досліджень, проте вони проводилися або в межах великих водосховищ Київського, Кременчуцького, Канівського, або на території об'єктів природно-заповідного фонду.

Серед основних напрямів вирішення вищенаведеної проблеми, виявлених у ресурсах світової наукової періодики, можуть бути виділені:

- дослідження молюсків (mussels Perna perna) як продукту харчування за показниками фізико-хімічних, харчових, показників безпеки та споживчих властивостей [6];

- оцінка гістопатологічного моніторингу мідій Perna perna та Itaipu Lagoon [7];

- вплив термічної та різних видів попередньої обробки (посол, маринування) на кінцеві характеристики м’яса мідій, а саме: вихід готового продукту й терміни зберігання, зниження кількості токсикантів [5].

Питання особливостей вмісту та розподілу важких металів в органах i тканинах гідробіонтів малих річок, зокрема на території Сумської області, залишилися переважно поза увагою дослідників.

Метою статті $\epsilon$ проведення дослідження і контроль кількості токсичних важких металів (кадмію, плюмбуму і цинку) у м’якому тілі молюсків роду Anodonta.

Викладення основних результатів дослідження. Одним із найбільш важливих факторів, які впливають на якість готової продукції, є стабільна екологічна чистота сировини. Враховуючи, що прісноводні двостулкові молюски є мешканцями як проточних, так і стоячих водойм, екологічна ситуація яких різко змінюється через техногенні й антропогенні фактори, визначення ступеня накопичення важких металів у їхньому м’якому тілі є актуальним.

Об'єктами дослідження були двостулкові молюски роду Anodonta, що є типовими представниками річкових двостулкових молюсків, які мешкають, переважно, в прибережній зоні на піщано-мулистому грунті з уповільненим плином течії. 3 огляду на вищевикладене можна припустити: по-перше, різний рівень забруднення у різних зонах проживання молюсків, а, по-друге, імовірну здатність цих видів до накопичення важких металів.

Збиралися молюски в р. Десна в іiі середній течії в районі села Пирогівка і в оз. Синювате, розташованому в Сумському районі, село Підліснівка. Дослідження вмісту важких металів у воді і м'якому тілі двостулкових молюсків були проведені за такими стандартами: ГОСТ 30178-96 « Сировина і продукти харчові. Атомно-абсорбційний метод визначення токсичних елементів» (спосіб сухого озолення), ICO 8288-86 «Якість води: визначення токсичних елементів, полум’яні атомно-абсорбційні спектрометричні методи».

Для оцінки ступеня акумуляції металів у тканинах молюсків щодо вмісту елементів у воді був розрахований коефіцієнт біологічного накопичення $\left(\mathrm{K}_{\mathrm{bH}}\right)$, під яким розуміють відношення концентрації важких металів в м'якому тілі прісноводних молюсків до їх кількісного вмісту в навколишньому середовищі.

За величиною акумуляції гідробіонти, в тому числі прісноводні молюски, поділяються на макро-, мікро-, деконцентратори [3]. До макроконцентраторів відносяться молюски, у яких $\mathrm{K}_{\mathrm{bH}}>15000$, до мікроконцентраторів молюски 3 $\mathrm{K}_{\mathrm{БH}}=10000-15000$, до деконцентраторів - $3 \mathrm{~K}_{\mathrm{5H}}<10000$. 
Таблиця 1. Вміст важких металів у воді і в тканинах двостулкових молюсків, $P \geq 95 \%, n=5$

\begin{tabular}{|c|c|c|c|c|}
\hline Об'єкт досліджень & $\mathrm{Cu}$ & $\mathrm{Zn}$ & $\mathrm{Pb}$ & $\mathrm{Cd}$ \\
\hline \multicolumn{5}{|c|}{ p. Десна } \\
\hline Вода (мг/л) & $0,019 \pm 0,0011$ & $0,029 \pm 0,007$ & - & $0,14 \pm 0,005$ \\
\hline Молюск (мг/кг) & $0,97 \pm 0,0017$ & $11,1 \pm 0,0011$ & - & $0,024 \pm 0,009$ \\
\hline \multicolumn{5}{|c|}{ оз. Синювате } \\
\hline Вода (мг/л) & $0,005 \pm 0,0011$ & $0,047 \pm 0,0011$ & - & $0,17 \pm 0,0011$ \\
\hline Молюск (мг/кг) & $0,78 \pm 0,0018$ & $9,31 \pm 0,005$ & - & $0,003 \pm 0,007$ \\
\hline
\end{tabular}

3 наведених у табл. 1 даних бачимо, що вміст токсичних металів не перевищує гранично допустимої концентрації по цинку, кадмію і плюмбуму, не зважаючи на їхню кількість у водних середовищах досліджуваних об'єктів. Це може бути пов'язано з способом життєдіяльності гідробіонтів. Своєю зовнішньою частиною і такими важливими органами, як зябра, молюски повністю занурені у воду, отже, дія розчинених речовин і їх концентрація у цих органах найбільша. Основна кількість іонів, які потрапляють до організму молюсків, проникає через зябра (до 70\%), дещо менше через мантію (до $20 \%$ ), а решта - через органи травлення. Разом з тим акумуляція плюмбуму проходила активніше, коли метал надходив через кишково-шлунковий тракт. Проте технологія напівфабрикату 3 молюска прісноводного передбачає видалення так званих неїстівних частин (зябер, кишківника, гонад). Крім токсикантів, у природних водах наявні розчинні нетоксичні речовини, що можуть зменшувати або збільшувати токсичність інших речовин шляхом зміни мембранної проникності.

Результати дослідження показали, що різні метали неоднаково накопичуються в тканинах досліджуваних молюсків (табл. 1). Цікаво відзначити, що досліджувані види двостулкових молюсків у найбільших кількостях накопичують цинк. Однак встановлено, що вміст усіх аналізованих металів у тілі молюсків роду Anodonta в різних водних системах неоднаковий. Так вміст цинку на $27 \%$ вищий в озері, ніж у проточній системі р. Десни, міді - на $18 \%$ менший. Проте така різниця пояснюється відповідним більшим (на 34\%) вмістом цинку в озері і меншим (на $22 \%$ ) вмістом міді. Свинець у досліджуваних пробах води р. Десни та озера Синювате не виявлено.

Отже, молюски роду Anodonta не становлять загрозу під час споживання. Різні види молюсків мають різну здатністю до акумуляції металів у своїх тканинах, що повністю підтверджує твердження В.I. Вернадського: «Однією 3 функції біосфери $є$ концентраційна». Ці висновки добре узгоджуються з розрахованими нами коефіцієнтами біологічного накопичення металів молюсками (К Бн) (табл. 2).

Таблиця 2. Коефіцієнти біологічного накопичення (Kd) металів у м'яких тканинах двостулкових молюсків, $P \geq 95 \%, n=5$

\begin{tabular}{|c|c|c|c|c|}
\hline Об'єкт досліджень & $\mathrm{K}_{\mathrm{БH}} \mathrm{Cu}$ & $\mathrm{K}_{\mathrm{LH}} \mathrm{Zn}$ & $\mathrm{K}_{\mathrm{БH}} \mathrm{Pb}$ & $\mathrm{K}_{\text {БH }} \mathrm{Cd}$ \\
\hline Молюск (мг/кг) & 48 & 547 & - & 20 \\
\hline
\end{tabular}


Аналіз накопичення іонів важких металів дав змогу узагальнити особливості їх кумуляції і вибудувати ряди накопичення, які мають загальні закономірності. Так для молюсків роду Anodonta:

$$
\mathrm{K}_{\mathrm{bH}} \mathrm{Zn}>\mathrm{K}_{\mathrm{bH}} \mathrm{Cu}>\mathrm{K}_{\mathrm{bH}} \mathrm{dCd}>\mathrm{K}_{\mathrm{6H}} \mathrm{dPb} \text {. }
$$

\section{Висновки}

Проведені дослідження свідчать про вплив різних чинників на накопичення токсичних металів у воді та м'якому тілі прісноводних молюсків. Доведено, що концентрації важких та інших токсичних іонів металів у досліджуваних складових гідроекосистеми водоймища корелюють з їхнім нормативним значенням. Вміст важких металів у тканинах досліджуваних видів молюсків перебуває в межах допустимих норм. Коефіцієнти біологічного накопичення свідчать не тільки про забруднення середовища цими металами, але і про біологічну доступність їхніх іонів за таких умов, а також вказують на невисоку акумуляцію мікроелементів молюсками.

\section{Література}

1. Andalecio Consumers' behavior towards cultured oyster and mussel in Western Visayas, Philippines / Merlina N. Andalecio, Ernestina M. Peralta, Ruby P. Napata, Liberato V. Laureta. Aquaculture, Aquarium, Conservation \& Legislation. 2014. No. 7(2). P. 116-136. URL: https://doaj.org/article/0c22a20963b849dab260b12b32fe091c.

2. Golovko N., Golovko T., Gelikh A. Investigation amino-acid structure of proteins bivalve freshwater Mussels from the family Anodonta of the northern Ukraine. EasternEuropean Journal of Enterprise Technologies. 2015. No. 5/11(77). P. 10-16.

3. Golovko N., Golovko T., Gelikh A. Investigation fatty acid and mineral of soft body bivalve freshwater mussels from the family Anodonta of the northern Ukraine. Technological Audit and Production Reserves. 2016. No. 3/3(29). P. 17-23.

4. Golovko N., Golovko T., Gelikh A. Research qualitative composition of minerals soft body freshwater bivalve mussels of the genus Anodonta and marine counterpart - the mussels of the genus Mytilus. Progressive engineering and technology of food production enterprises, catering business and trade. 2015. No. 2(22). P. 270-278.

5. Marušić Nives, Vidaček Sanja, Medić Helga, Petrak Tomislav GROWTH OF MUSSELS (Mytilus galloprovincialis) ON THE EAST COAST OF ISTRIA. Croatian Journal of Fisheries. 2010. No. 68(1). P. 19-25. URL: https://doaj.org/article/1c0507ec8da6484d8ee80fd00ce4cf89.

6. Érika Fabiane Furlan Physicochemical stability and market of mussels (Perna perna) cultivated in Ubatuba - SP, Brasil / Érika Fabiane Furlan, Juliana Antunes Galvão, Eduardo Oliveira Salán, Viviane Angeli Yokoyama, Marília Oetterer. Food Science and Technology. 2007. No. 27(3). P. 516-523. URL: https://doaj.org/article/3df4a621844642b1b243caf6853603ad.

7. Lima F.C., Abreu M.G., Mesquita E.F.M. Histopathological monitoring assessment of mussels Perna perna at the Itaipu Lagoon, Brazil. Arquivo Brasileiro de Medicina Veterinária e Zootecnia. 2001. No. 53(2). P. 1-5. URL: https://doaj.org/article/40c1d861d213406493b604b6ce2ac6ab/

8. Giustino Tribuzi, Gláucia Maria Falcão de Aragao, João Borges Laurindo Processing of chopped mussel meat in retort pouch. Food Science and Technology. 2015. vol. 35, No. 4. P. 612 -619. URL: https://doaj.org/article/dda612fcc5db4492b8210828bd19a72a. 